Craft, I. (1973). Fournal of Obstetrics and Gynaecology of the British Commonweatlh, 80, 46

Embrey, M. P., Hillier, K., and Mahendran, P. (1972). British Medical fournal, 3, 146

Lippert, T. H., and Modly, T. (1973). Fournal of Obstetrics and Gynaecology of the British Commonwealth, 80, 1025.

MacKenzie, I. Z., Embrey, M. P., and Hillier, K. (1974). Fournal of Obstetrics and Gynaecology of the British Commonwealth, 81, 554.
MacKenzie, I. Z., and Hillier, K. (1974), Lancet, 1, 511.

Midwinter, A., Shepherd, A., and Bowen, M. (1973). Fournal of Obstetrics and Gynaecology of the British Commonwealth, 80, 371.

Miller, A. W. F., Calder, A. A., and MacNaughton, M. C. (1972). Lancet, 2,5 .

Read, M. D., Bedford, N. A., and Martin, R. H. (1974). Lancet, 1, 214.

Wiqvist, N., et al, (1972). Prostaglandins in Fertility Control, 2, 118.

Wiqvist, N., et al, (1974). Prostaglandins, 6, 193.

\title{
Electrocardiographic Abnormalities Associated with Raised Intracranial Pressure
}

\author{
S. J. JACHUCK, P. S. RAMANI, F. CLARK, R. M. KALBAG
}

British Medical fournal, 1975, 1, 242-244

monitored by placing a pressure-sensitive transducer in the extradural space as part of a different study. To the best of our

\section{Summary}

Serial electrocardiographic (E.C.G.) recordings were taken in seven patients suffering from intracranial conditions, for which their intracranial pressure was directly and continuously monitored with a Konigsberg extradural transducer. The E.C.G. changes observed in patients with raised intracranial pressure were prominent $U$ waves, ST-T segment changes, notched $T$ waves, and shortening and prolongation of Q-T intervals. Two patients with normal intracranial pressure showed no E.C.G. abnormalities. The results not only confirm the association between central nervous system diseases and E.C.G. abnormalities but also establish a relationship between E.C.G. abnormalities and changing intracranial pressure.

\section{Introduction}

Electrocardiographic (E.C.G.) abnormalities are known to occur in a variety of central nervous system lesions like subarachnoid haemorrhage, cerebrovascular accidents, head trauma, intracranial space-occupying lesions, meningitis, etc. (Byer et al., 1947; Burch et al., 1954; Schuster, 1960; Finkelstein and Nigaglioni, 1961; Hersch, 1961, 1964; Fentz and Gormsen, 1962; Goldman, 1967; Abildskov et al., 1970; Cruickshank and Dwyer, 1974). Bradycardia, extrasystoles, abnormal ST-T deflection, tall, deeply inverted, or notched $T$ waves, prominent $\mathrm{U}$ waves, and prolonged Q-T intervals have been described. The possible mechanism responsible for these changes has been discussed by Abildskov et al. (1970), who concluded that the E.C.G. abnormalities may be mediated by abnormalities of the sympathetic tone to the heart. Raised intracranial pressure as judged by isolated readings of cerebrospinal fluid pressure at lumbar puncture was thought not to be responsible for E.C.G. abnormalities (Hersch, 1964). It is now well established that intracranial pressure is not a static phenomenon and its dynamics can only be assessed by measuring it directly and continuously (Lundberg, 1960; Langfitt, 1969).

We describe here seven patients in whom serial E.C.G.s were recorded while their intracranial pressure was continuously

\footnotetext{
Departments of Neurosurgery and Medicine, Newcastle General Departments of Neurosurgery and Medicin

S. J. JACHUCK, M.B., B.S., Honorary Clinical Research Assistant in Medicine and Cardiology

P. S. RAMANI, M.S., M.SC., Senior Registrar in Neurosurgery

F. CLARK, F.R.C.P., Consultant Physician

R. M. KALBAG, F.R.C.s., Consultant Neurosurgeon
}

\section{Patients and Methods}

Seven patients with varying intracranial conditions and with no evidence of cardiovascular disease were assessed. The intracranial pressure was continuously monitored using a Konigsberg extradural transducer. Whenever the intracranial pressure changed 12-lead E.C.G.s were recorded. Serum electrolytes and blood gases were also assessed in all these patients. Intracranial pressure was measured in millimetres of mercury $(1 \mathrm{~mm} \mathrm{Hg}=$ $0.13332 \mathrm{kPa}$ ) and $15 \mathrm{~mm} \mathrm{Hg}$ was considered as the upper limit of normal. The intracranial pressure was above normal limits in five patients. A combination of dexamethasone and glycerol was used to lower the intracranial pressure to within normal limits and E.C.G. abnormalities were recorded several times as the intracranial pressure changed. In the remaining two patients who were admitted with head injuries the intracranial pressure was within normal limits throughout and they did not show any E.C.G. abnormalities.

\section{Case Reports}

Case 1.-A 47-year-old man was admitted with a head injury. He had had no previous cardiac disability. His blood pressure remained between 130 and $150 \mathrm{~mm} \mathrm{Hg}$ systolic and between 80 and 90 $\mathrm{mm} \mathrm{Hg}$ diastolic throughout the period of illness. The intracranial pressure went up to $45 \mathrm{~mm} \mathrm{Hg}$, and with the changing pressure the E.C.G. abnormalities recorded were tachycardia, changes in ST-T segment, $U$ waves, changes in voltage, and shortening of Q-T interval (fig. 1).

Case 2.-A man aged 50 years with benign intracranial hypertension and with no cardiac disability was admitted for investigations and treatment of raised intracranial pressure. His blood pressure throughout was around $140 / 85 \mathrm{~mm} \mathrm{Hg}$. The E.C.G. abnormalities with changing intracranial pressure were tachycardia, $\mathrm{S}-\mathrm{T}$ depression, $\mathrm{U}$ waves, and shortening of $\mathrm{Q}-\mathrm{T}$ interval as shown in the table.

Case 3.-A 43-year-old man was admitted with right temporal lobe tumour (glioma). His blood pressure throughout was $130 / 90$ $\mathrm{mm} \mathrm{Hg}$. With changing intracranial pressure the E.C.G. abnormalities noted in him were a slightly raised S-T segment, $U$ waves, and prolongation of Q-T intervals as shown in the table.

Case 4.-A 45-year-old woman was admitted with recurrent tumour of right cerebral hemisphere (glioma). Her systolic blood pressure varied between 145 and $160 \mathrm{~mm} \mathrm{Hg}$ and her diastolic pressure was $90 \mathrm{~mm} \mathrm{Hg}$. The intracranial pressure at one time had gone up to $65 \mathrm{~mm} \mathrm{Hg}$. Bradycardia, progressive T-wave inversion, $U$ waves, and shortening of the Q-T interval were the abnormalities recorded in her E.C.G.s (fig. 2).

Case 5.-A 21-year-old man was admitted with a head injury. He had sustained extensive cerebral contusion and his intracranial 
pressure at one time was $85 \mathrm{~mm} \mathrm{Hg}$. He had no past history of cardiac disability and did not drink alcohol. Notched $T$ waves were the only abnormality observed in his E.C.G.s (fig. 3).

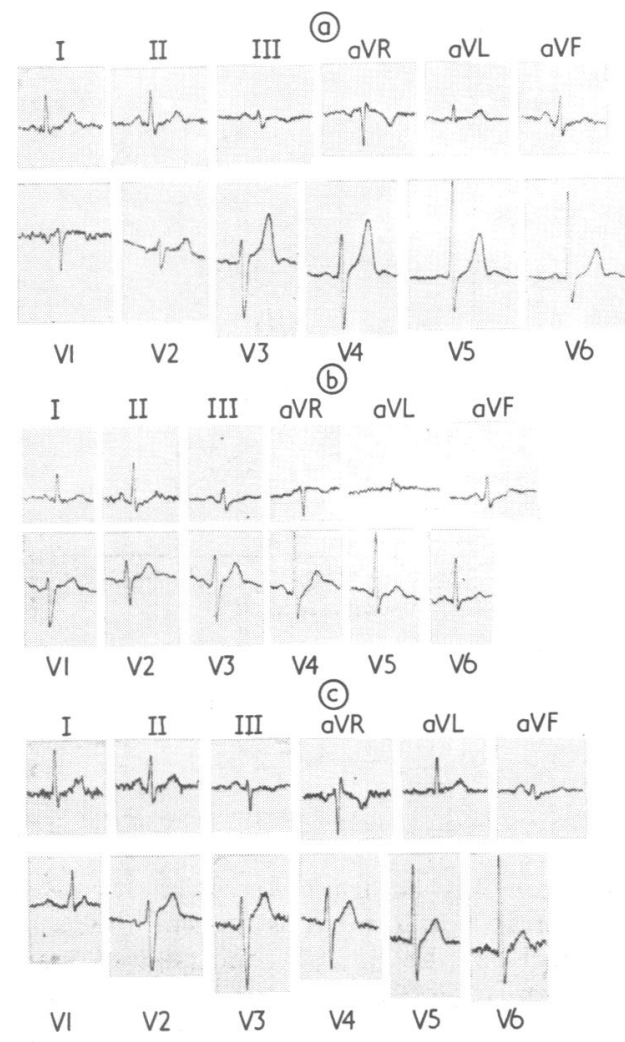

FIG. 1-Case 1. E.C.G.s at intracranial pressures of (a) 15, (b) 45, and (c) 5 $\mathrm{mm} \mathrm{Hg}$ showing tali $\mathrm{T}$ waves in (a), flat ones in (b), and normal ones in (c). $\mathrm{U}$ waves are seen only in (a) and (b). Voltage decreased with rising pressure.

\section{Results and Discussion}

The two patients with normal intracranial pressure showed no E.C.G. abnormalities. The remaining five patients with raised intracranial pressure showed normal sinus rhythm. With changing pressures certain E.C.G. abnormalities were observed.

Rate. - In two patients (cases 1 and 2) the heart rate increased as the intracranial pressure went up to $45 \mathrm{~mm} \mathrm{Hg}$ and $30 \mathrm{~mm} \mathrm{Hg}$ respectively. Both these patients were restless. The heart rate in two other patients (cases 3 and 4) became slower as the intracranial pressure went up to $125 \mathrm{~mm} \mathrm{Hg}$ and $65 \mathrm{~mm} \mathrm{Hg}$ respectively. These two patients were comatose. It seems that the Cushing response (Cushing, 1902) starts appearing above an intracranial pressure of $45 \mathrm{~mm} \mathrm{Hg}$, when the patient is drowsy
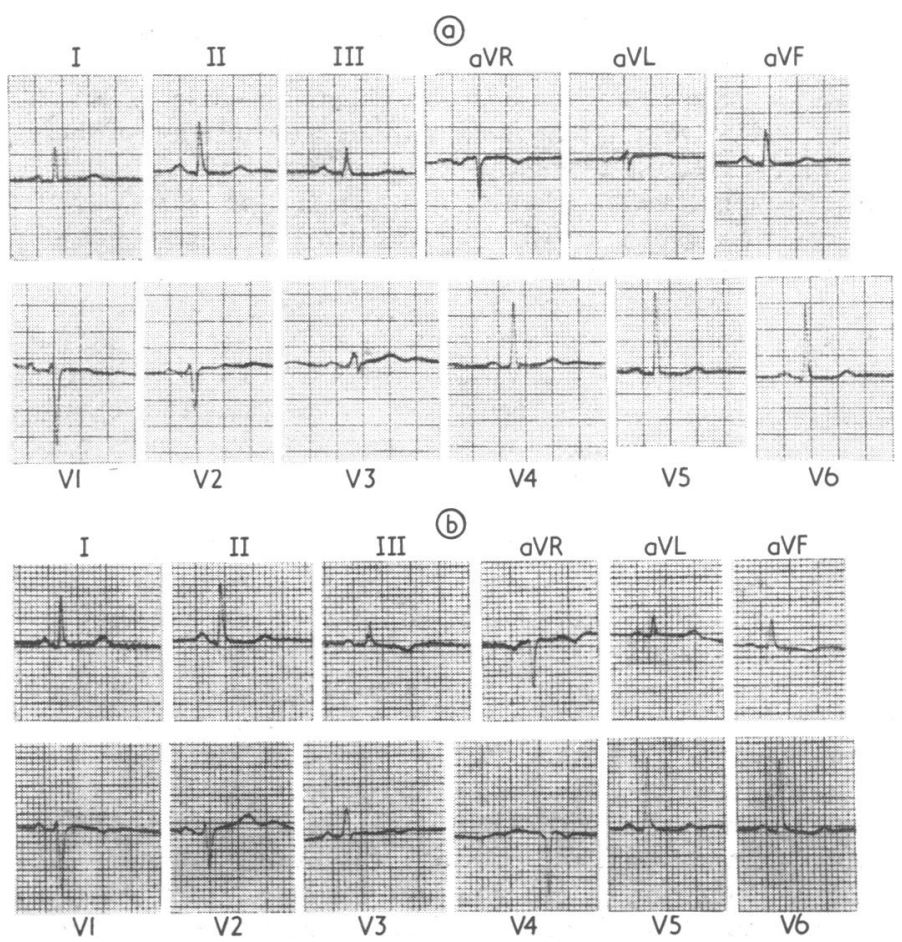

FIG. 2-Case 4. E.C.G.s at intracranial pressures of (a) 30 and (b) $65 \mathrm{~mm} \mathrm{Hg}$ showing progressive $T$ wave changes and presence of $U$ waves.

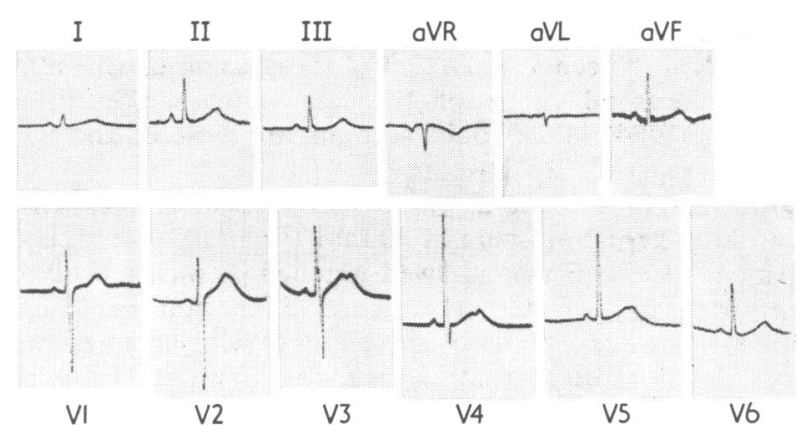

FIG. 3-Case 5. E.C.G. at intracranial pressure of $85 \mathrm{~mm} \mathrm{Hg}$ showing notched $\mathrm{T}$ waves.

and not restless. According to Burch et al. (1954) in patients with cerebrovascular accidents the heart does not exceed $100 / \mathrm{min}$, but in one of our patients (case 1) the heart rate had gone up to $115 / \mathrm{min}$ when the intracranial pressure was $45 \mathrm{~mm} \mathbf{~ H g}$.

$T$ Waves. - In all five patients the $\mathrm{T}$ waves were abnormal.

Various Electrocardiographic Abnormalities noted in Five out of Seven Patients with High Intracranial Pressure (I.C.P.). E.C.G. Abnormalities have been Correlated to Changing Intracranial Pressure

\begin{tabular}{|c|c|c|c|c|c|c|c|c|c|c|c|}
\hline \multirow{3}{*}{$\begin{array}{l}\text { I.C.P. } \\
(\operatorname{mm} \mathbf{H g}): \\
\text { Rate/min } \\
\text { T Wave }\end{array}$} & \multicolumn{3}{|c|}{ Case 1} & \multicolumn{2}{|c|}{ Case 2} & \multicolumn{3}{|c|}{ Case 3} & \multicolumn{2}{|c|}{ Case 4} & \multirow{3}{*}{$\begin{array}{c}\text { Case 5 } \\
85 \\
79 \\
\text { Notched in } \\
\text { II, V2-5 } \\
\text { Normal }\end{array}$} \\
\hline & 15 & 45 & 5 & 10 & 30 & 45 & 125 & 10 & 30 & 65 & \\
\hline & $\begin{array}{c}100 \\
\text { Tall in V3-6 }\end{array}$ & Flat & $\begin{array}{c}100 \\
\text { Normal }\end{array}$ & Flat in aVL & Flat in aVL & $\begin{array}{c}71 \\
\text { Flat in } 1,\end{array}$ & $\begin{array}{c}68 \\
\text { Flat in III, }\end{array}$ & $\begin{array}{l}79 \\
\text { Flat in aVL }\end{array}$ & $\begin{array}{l}70 \\
\text { Flat in III, }\end{array}$ & $\begin{array}{c}63 \\
\text { Inverted in }\end{array}$ & \\
\hline $\begin{array}{l}\text { U Wave } \\
\text { Voltage SV2 } \\
+ \text { RV } 5(\mathrm{~mm})\end{array}$ & Normal & 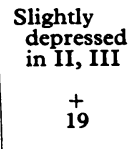 & $\begin{array}{r}\text { Absent } \\
27\end{array}$ & 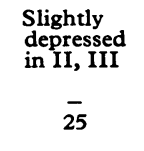 & $\begin{array}{c}\text { More } \\
\text { depressed } \\
\text { in II, III, } \\
\text { aVF } \\
+ \\
\quad 24\end{array}$ & $\begin{array}{l}\text { Slightly } \\
\text { raised in } \\
\text { II, III, } \\
\text { aVF } \\
+ \\
28\end{array}$ & $\begin{array}{l}\text { avL } \\
\text { Slightly } \\
\text { raised in } \\
\text { II, III, } \\
\text { aVF } \\
+ \\
+\end{array}$ & Normal & Normal & Normal & Normal \\
\hline $\begin{array}{l}\text { P-R Period (s) } \\
\text { R-R Period (s) } \\
\text { QRS } \\
\text { Complex (s) }\end{array}$ & $\begin{array}{l}0.14 \\
0.60 \\
0.08\end{array}$ & $\begin{array}{l}0.14 \\
0.52 \\
0.06\end{array}$ & $\begin{array}{l}0.14 \\
0.60 \\
0.08\end{array}$ & $\begin{array}{l}0.2 \\
0.7 \\
0.08\end{array}$ & $\begin{array}{l}0.18 \\
0.64 \\
0.06\end{array}$ & $\begin{array}{l}0.18 \\
0.84 \\
0.06\end{array}$ & $\begin{array}{l}0.18 \\
0.88 \\
0.06\end{array}$ & $\begin{array}{l}0.16 \\
0.76 \\
0.04\end{array}$ & $\begin{array}{l}0.18 \\
0.86 \\
0.08\end{array}$ & $\begin{array}{l}0.16 \\
0.96 \\
0.08\end{array}$ & $\begin{array}{l}0.12 \\
0.76 \\
0.06\end{array}$ \\
\hline $\begin{array}{c}\text { Q-T Period (s) } \\
\text { Corrected }\end{array}$ & 0.44 & 0.39 & 0.41 & 0.43 & $0 \cdot 40$ & 0.39 & 0.40 & 0.39 & 0.41 & 0.39 & 0.42 \\
\hline
\end{tabular}


They were flat in three patients, notched in one patient, and tall in the other. The tall $T$ waves of the type described by Burch et al. (1954) and Schuster (1960) in patients with cerebrovascular diseases were seen in only one of our patients (case 1 ). Burch et al. (1954) have said that the amplitude and duration of these $\mathrm{T}$ waves are greatest during the period of bradycardia. but tall $\mathrm{T}$ waves seen in case 1 , when the intracranial pressure was 15 $\mathrm{mm} \mathrm{Hg}$, were associated with tachycardia. We suggest that tall $T$ waves are an early E.C.G. manifestation of rising intracranial pressure. In case 1 the tall $T$ waves became flat as the intracranial pressure went up to $45 \mathrm{~mm} \mathrm{Hg}$ and reverted to normal as the intracranial pressure was brought down to $5 \mathrm{~mm} \mathrm{Hg}$. The $T$ waves became progressively inverted in case 4 when the pressure went up to $65 \mathrm{~mm} \mathrm{Hg}$. These $\mathrm{T}$ wave changes were usually seen in the standard leads II, III, aVL, and aVF. Notched $T$ waves best seen in the chest leads were seen in only one patient (case 5) when the I.C.P. was $85 \mathrm{~mm} \mathrm{Hg}$. Though it is reported that notched $T$ waves can also occur in patients with alcoholic heart disease our patient who showed notched $\mathrm{T}$ waves was a total abstainer.

$S-T$ Segment.-Only two patients (cases 1 and 2) showed progressive $S-T$ depression with increasing intracranial pressure. These changes, like $T$ wave changes, were best seen in standard leads II, III, aVL, and aVF. In one patient (case 3 ) the S-T segment was raised with high intracranial pressure, and it became normal when the pressure was brought down to 10 $\mathrm{mm} \mathrm{Hg}$. The changes were similar to those seen in myocardial ischaemia but these changes subsided as the raised intracranial pressure was brought down to normal levels. This would also suggest that E.C.G. changes seen in central nervous system lesions are often reversible and therefore unlikely to be due to any structural damage in the central nervous system. Myocardial damage associated with intracranial bleeding has been described (Smith and Tomlinson, 1954; Koskelo et al., 1964; Abildskov et al., 1970); it is seen in only $12.3 \%$ of cases and usually affects the subendocardial tissue of the left ventricle (Smith and Tomlinson, 1954). This could account for some of the ST-T segment changes.

$U$ Waves.-Prominent $U$ waves were seen in all the patients with an intracranial pressure of $30 \mathrm{~mm} \mathrm{Hg}$ and above except in the patient in case 5 who showed notched $T$ waves. Only one patient with an intracranial pressure of $15 \mathrm{~mm} \mathrm{Hg}$ showed prominent $U$ waves. None of the patients with an intracranial pressure lower than $15 \mathrm{~mm} \mathrm{Hg}$ showed $U$ waves. Prominent $U$ waves were best seen in the chest leads. In two patients the $U$ waves disappeared as the raised intracranial pressure was brought down to within normal levels.

Voltage.-Changing intracranial pressure has no effect on the voltage of the QRS complex and it remained within the normal range in four patients. In case 1 voltage diminished with the increasing intracranial pressure but it again became normal as the pressure was brought down to $5 \mathrm{~mm} \mathrm{Hg}$.

$P-R$ and $Q R S$ Intervals. - These intervals remained within the normal range in all the patients with intracranial pressure up to $30 \mathrm{~mm} \mathrm{Hg}$. The QRS duration remained between 0.06 and 0.08 seconds when the intracranial pressure rose above $30 \mathrm{~mm} \mathrm{Hg}$. In only one patient (case 2 ) the QRS duration was 0.18 seconds. No other conduction defect was seen.

$Q-T$ Interval.- The Q-T intervals were corrected for their $\mathbf{R}-\mathbf{R}$ intervals. Initial $\mathrm{Q}-\mathrm{T}$ intervals ranged from 0.39 to 0.43 seconds. The Q-T intervals became shorter as the intracranial pressure increased except in case 3 where the intracranial pressure went up to $120 \mathrm{~mm} \mathrm{Hg}$ and the Q-T interval became more prolonged. The relationship between $\mathrm{Q}-\mathrm{T}$ interval and the intracranial pressure is shown in fig. 4. Contrary to the current concept, the Q-T interval became shorter as the intracranial pressure went up to $65 \mathrm{~mm} \mathrm{Hg}$. In case 3 the Q-T interval became more prolonged as the pressure went up to $120 \mathrm{~mm} \mathrm{Hg}$. It is suggested that initially the Q-T interval shortens until the intracranial pressure reaches $65 \mathrm{~mm} \mathrm{Hg}$, but thereafter it becomes more prolonged (case 3 ) when the pressure rises higher than $65 \mathrm{~mm} \mathrm{Hg}$. Thus, a prolonged Q-T interval might be an ominous sign.

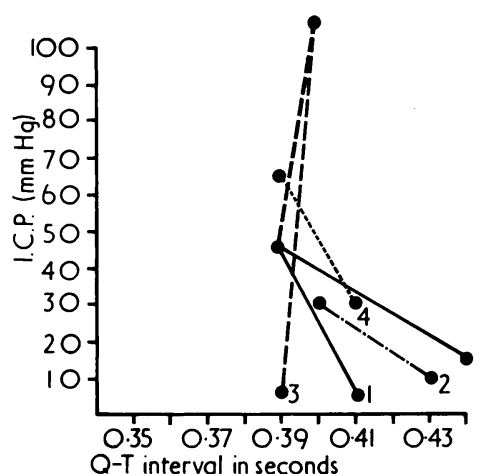

FIG. 4-Q-T intervals in relation to intracranial pressure (I.C.P.) Q-T interval progressively shortens as intracranial pressure rises except in case 3 in which $\mathrm{Q}-\mathrm{T}$ interval was prolonged when intracranial pressure was $125 \mathrm{~mm} \mathrm{Hg}$.

\section{CONCLUSION}

These findings not only confirm the association between E.C.G. abnormalities and central nervous system diseases but also suggest that many of the E.C.G. abnormalities are related to changing intracranial pressure. There has been a certain amount of doubt about the role of intracranial pressure in the production of E.C.G. abnormalities. But never before have E.C.G. changes been correlated with direct and continuous monitoring of intracranial pressure. With the advancement in technology mosı neurosurgical centres today accept direct and continuous monitoring of intracranial pressure as an important index in the treatment of patients. By using this facility it is hoped to evaluate the pathophysiology of these changes more thoroughly.

We thank Dr. M. Tynan, consultant paediatric cardiologist, for his guidance; the department of photography, University of Newcastle upon Tyne, for the illustrations; and Mrs. E. Matthews for secretarial help. This work was supported by a research grant to the department of neurosurgery from the Northern Regional Area Health Authority.

\section{References}

Abildskov, J. A., et al. (1970). Progress in Cardiovascular Diseases, 13, 210. Byer, E., Ashman, R., and Toth, L. A. (1947). American Heart fournal, 33,

Burch, G. E., Meyers, R., and Abildskov, J. A. (1954). Circulation, 9, 719. Cushing, H. (1902). American fournal of Medical Science, 124, 375.

Cruickshank, J. M., and Dwyer, G. N. (1974). British Heart fournal, 36, 395. Fentz, V., and Gormsen, J. (1962). Circulation, 25, 22.

Finkelstein, D., and Nigaglioni, A. (1961). American Heart fournal, 62, 772. Goldman, M. J. (1967). Principles of Electrocardiology, 6th edn., p. 282. Los Altos, California, Lange.

Hersch, C. (1961). Circulation, 28, 853.

Hersch, C. (1964). British Heart fournal, 26, 785

Koskelo, P., Punsar, S., and Sipila, W. (1964). British Medical fournal, 1, 1479 .

Langfitt, T. W. (1969). Clinical Neurosurgery, 16, 436.

Lundberg, N. (1960). Acta Psychiatrica Neurologica Scandinavica, 36, Suppl. 149.

Schuster, S. (1960). British Heart fournal, 22, 316.

Smith, R. P., and Tomlinson, B. E. (1954). Fournal of Pathology and Bacteriology, 68, 327. 